\title{
Production within dense mats of the filamentous macroalga Chaetomorpha linum in relation to light and nutrient availability
}

\author{
Dorte Krause-Jensen*, Karen McGlathery, Søren Rysgaard, Peter Bondo Christensen
}

National Environmental Research Institute, Vejlsøvej 25, PO Box 314, DK-8600 Silkeborg, Denmark

\begin{abstract}
Dense mats of Chaetomorpha linum were incubated in the laboratory at low and high surface irradiance and were enriched by a simulated sediment nutrient flux. Algal activity resulted in marked diurnal variations and steep vertical gradients in $\mathrm{O}_{2}$ and $\mathrm{NH}_{4}{ }^{+}$concentration profiles within the mats. In the light, $\mathrm{O}_{2}$ production caused supersaturation in the surface layers, and algal assimilation significantly reduced the flux of nutrients to the water column. The depth gradients of decreasing light and increasing nutrient availability within the mat were reflected in the algal tissue composition. At high surface irradiance, chlorophyll concentrations increased towards the bottom of the mat and $\mathrm{C} / \mathrm{N}$ ratios gradually declined. This pattern suggested light limitation in the bottom of the mat and progressive $N$ limitation towards the mat surface. Algal productivity declined with depth in the mats, reflecting a pronounced self-shading, and the photic zone (i.e. the depth of $1 \%$ surface irradiance) was only $8 \mathrm{~cm}$ deep. Productivity per unit volume was high, and comparisons to communities of other benthic macrophytes, benthic microalgae, and phytoplankton dernonstrated a general pattern of increasing volume-specific productivity at decreasing extension of the photic zone, whereas the area productivity (depth-integrated) of the different plant communities is remarkably uniform. As algal density and selfshading increases, the algal mats can switch from being net productive to a status where consumption exceeds production. Reduced irradiance and increased water temperature may also trigger this shift, and the resulting effects on $\mathrm{O}_{2}$ and nutrient balances make shallow macroalgal-dominated systems inherently unstable.
\end{abstract}

KEY WORDS: Macroalgal mats Chaetomorpha linum - Light · Production - Oxygen - Nutrients Chlorophyl] . Tissue composition - Microelectrodes

\section{INTRODUCTION}

Ephemeral macroalgae are often the dominant primary producers in shallow, eutrophic bays where they may form dense mats on the sediment surface (Sfriso et al. 1987, Lavery et al. 1991, Valiela et al. 1992). The development of algal mats can be important to the nutrient dynamics of coastal waters because actively growing mats may intercept the nutrient flux from the sediment to the water column (K. McGlathery, D. Krause-Jensen, S. Rysgaard \& P. B. Christensen unpubl.).

\footnotetext{
•E-mail: fvdkj@dmu.dk
}

Light and nutrients are important regulating factors of macroalgal growth and productivity. Growth can be described as a saturating function of both irradiance (Sand-Jensen \& Madsen 1991) and tissue nutrient content (Lavery \& McComb 1991a, Pedersen 1993), but light and nutrient effects are also strongly interactive (Lapointe \& Tenore 1981, Coutinho \& Zingmark 1993). The relative importance of these growth limiting factors typically changes over the season. Light is the major limiting factor during winter and early spring when nutrients are in ample supply, whereas nutrients usually limit production during summer when nutrient availability is low and light availability is higher (Olesen 1989, Pedersen 1993). In addition, spatial differences between nutrient and light limitation may occur 
within the same estuary between shallow versus deep sites and between nutrient-poor versus nutrient-rich regions (Christensen et al. 1994). Macroalgae can acclimate to these variations in light and nutrient availability through biochemical changes to maximize photosynthetic capacity and growth. For example, tissue $\mathrm{N}$ and pigment contents tend to increase when irradiance decreases (Markager \& Sand-Jensen 1994 and references therein) and when $\mathrm{N}$ availability increases (Bird et al. 1982, Lapointe \& Duke 1984).

The relative importance of nutrients and light as growth regulating factors can also be expected to vary on a vertical scale within dense algal mats, since the microclimate can vary significantly from the surface to bottom layers of the mat (Lavery \& McComb 1991b, Thybo-Christesen et al. 1993, Christensen et al. 1994). While seaweeds typically obtain nutrients from the water column, dense macroalgal mats may also benefit from sediment nutrient sources. A gradient in ambient nutrient concentrations may develop within algal mats, as the availability decreases with distance from the sediment (Lavery \& McComb 1991b, Thybo-Christesen et al. 1993, McGlathery et al. unpubl.). Decomposition and mineralization of organic bound nutrients in the bottom layers of dense algal mats may provide an additional nutrient source within the mats (ThyboChristesen \& Blackburn 1993. McGlathery et al. unpubl.). High algal density, on the other hand, also creates pronounced self-shading, which results in decreasing light availability from the surface to bottom layers of the algal mats (Gordon \& McComb 1989).

The purpose of this work was to study macroalgal productivity in relation to the vertical gradients of light and nutrient availability created within dense algal mats and to determine the effect of macroalgal mats on oxygen and nutrient concentrations in the water column during situations of net growth and net decomposition of the algal biomass.

\section{MATERIALS AND METHODS}

Experimental setup. An experimental setup simulating an algal mat/sediment system was constructed in the laboratory using a 2-compartment Plexiglass cylinder (inner diameter $10 \mathrm{~cm}$, height $40 \mathrm{~cm}$; Fig. 1). The filamentous macroalga Chaetomorpha linum was collected in the shallow cove Kertinge Nor, Denmark, and added to the upper compartment to create a $15 \mathrm{~cm}$ thick algal mat comparable to in situ conditions. The algal mat consisted of $30 \mathrm{~g}$ (fresh weight, $\mathrm{fw}$ ) actively growing algae overlying $5 \mathrm{~g}$ fw of black algal filaments taken from the bottom of an algal mat. This density corresponds to $4.5 \mathrm{~kg} \mathrm{fw} \mathrm{m}^{-2}$ (or approximately $600 \mathrm{~g}$ $\mathrm{dw} \mathrm{m}^{2}$ ), which resembles the maximum biomass of

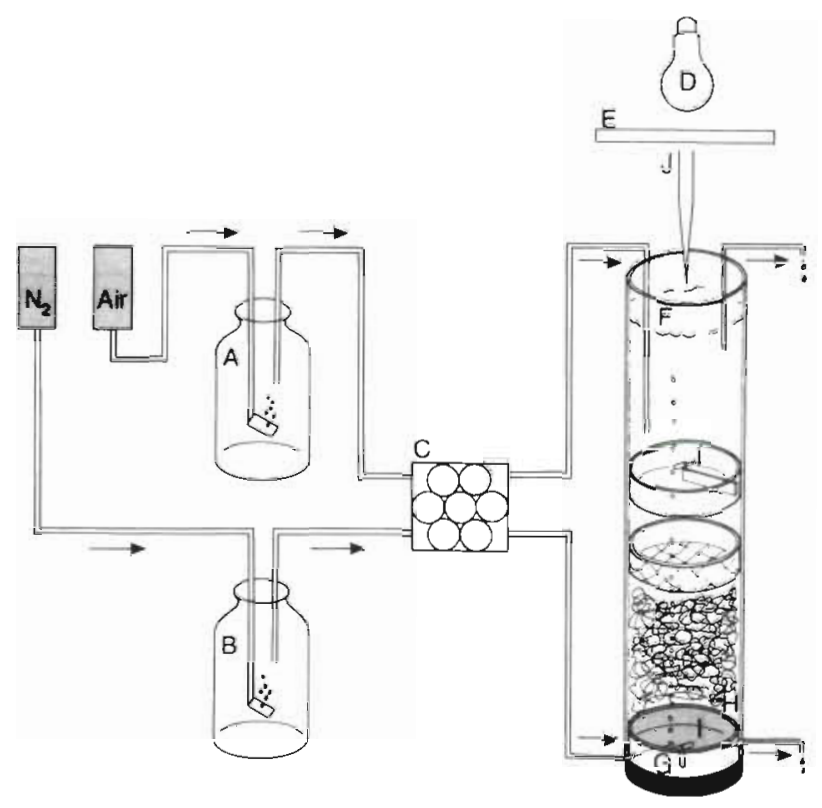

Fig. 1. Experimental setup. A: reservoir containing artificial seawater without nutrients; $B$ : reservoir containing artificial seawater-nutrient solution; C: peristaltic pump; D: $400 \mathrm{~W}$ mercury lamp; E: acrylic box continuously flushed with cold water to absorb heat radiation from the lamp; $F$ : upper compartment containing the algal mat; $\mathrm{G}$ : lower compartment flushed with nutrient solution; $\mathrm{H}$ : filter paper separating the 2 compartments; i: teflon-coated magnets driven by a large external rotating magnet; $\mathrm{J}: \mathrm{O}_{2}$ microsensor

algal mats recorded in the field (Sfriso et al. 1987, 1993, Lavery et al. 1991, Valiela et al. 1992, Ertebjerg et al. 1993, Viaroli et al. 1993). Nutrient efflux from the sediment was simulated by pumping a concentrated nutrient solution through the lower compartment causing nutrients to diffuse into the algal mat across a filter paper separating the 2 compartments. The flux rate was controlled by regulating the flow rate of nutrients through the lower compartment. The algae were allowed to adapt to these experimental conditions for $6 \mathrm{~d}$ before sampling was initiated.

The upper compartment received a continuous supply of artificial seawater $(17 \%$, Grasshoff et al. 1983) without any nutrients added. The seawater was pumped into the compartment at a flow rate of $3.2 \mathrm{ml}$ $\mathrm{min}^{-1}$ from an aerated reservoir to stabilize $\mathrm{O}_{2}$ and $\mathrm{CO}_{2}$ concentrations. The water column above the algal mat was stirred by a magnetic stirrer bar (60 rpm) positioned $5 \mathrm{~cm}$ above the mat surface.

Nutrients were added to artificial seawater in the lower compartment to reach a final concentration of $650 \mu \mathrm{M} \mathrm{NH}_{4}{ }^{+}$and $65 \mu \mathrm{M} \mathrm{PO}_{4}{ }^{3-}$. The nutrient solution was aerated with $\mathrm{N}_{2}$ to make the water anoxic before it was pumped through the lower compartment. Several tests of the outflowing water verified that bacterial growth (e.g. of nitrifying bacteria) in the lower cham- 
ber was negligible. The nutrient concentrations and flow rate were chosen to obtain an efflux of approximately $1000 \mu \mathrm{mol} \mathrm{N} \mathrm{m}^{-2} \mathrm{~h}^{-1}$ and $100 \mu \mathrm{mol} \mathrm{P} \mathrm{m}^{-2} \mathrm{~h}^{-1}$, corresponding to the maximum in situ flux rates during summer from the sediments in Kertinge Nor (Christensen et al. 1994). The flow rate ( $f$ ), and the concentrations of nutrients in the inflow $\left(C_{\mathrm{i}}\right)$ and the outflow $\left(C_{e}\right)$ were measured every 3 to $5 \mathrm{~h}$ during the experiment, and the actual flux rate $(F)$ was calculated as:

$$
F=\left(C_{1}-C_{e}\right) \times f / A
$$

where $A$ is the surface area separating the 2 chambers.

Light was supplied from a $400 \mathrm{~W}$ mercury lamp in a $12 \mathrm{~h}$ light/12 h dark cycle. One core received approximately $120 \mu \mathrm{mol}$ photons $\mathrm{m}^{-2} \mathrm{~s}^{-1}$ (referred to as 'low light') while the other core received approximately 380 $\mu \mathrm{mol} \mathrm{m} \mathrm{m}^{-2} \mathrm{~s}^{-1}$ ('high light'). The cores were wrapped in black plastic to prevent light exposure through the sides. The experiments were run in a temperaturecontrolled room at 18 to $21^{\circ} \mathrm{C}$.

Oxygen and nutrient concentrations within the mats. Oxygen profiles within the algal mats were measured by a Clark-type oxygen microsensor (Revsbech 1989). The electrode was directed down through the algal mat at $1 \mathrm{~mm}$ increments. Two-point calibration of the microsensor was performed regularly by taking readings in aerated and anoxic water. Immediately after recording an oxygen profile, a depth profile of the water was sampled for analysis of $\mathrm{NH}_{4}^{+}$concentrations. The water samples $(2 \mathrm{ml})$ were taken with syringes through silicone-stoppered ports located at $1 \mathrm{~cm}$ intervals in the Perspex wall and immediately frozen. The $\mathrm{NH}_{4}{ }^{+}$concentration was determined by the salicylate-hypochlorite method (Bower \& Hansen 1980). The data presented in the figures are typical results from a single experiment.

Algal production estimated from $\mathrm{O}_{2}$ concentration profiles. Depth profiles of $\mathrm{O}_{2}$ were measured 6 to 10 times during the light cycle and 3 to 6 times during the dark cycle. The net $\mathrm{O}_{2}$ production rates of the algal mats were calculated from the changes in $\mathrm{O}_{2}$ concentrations of the water column obtained from integration of successive $\mathrm{O}_{2}$ concentration profiles. The exchange of $\mathrm{O}_{2}$ with the water pumped through the upper chamber was calculated from Eq. (1) and included in the $\mathrm{O}_{2}$ budget.

Algal production estimated by ${ }^{13} \mathrm{C}$ uptake. On the last day of each experiment, $\mathrm{NaH}^{13} \mathrm{CO}_{3}$ was carefully injected into the mat to create a homogenous concentration of 20 to $50 \mu \mathrm{M}$ throughout the algal mat. After incubation, the algal mat was separated into $2 \mathrm{~cm}$ depth sections. The tissue was rinsed in demineralized water and freeze dried for $16 \mathrm{~h}$ for later analysis of total $\mathrm{C}$ content and ${ }^{13} \mathrm{C}$ atomic \% on a mass spectrometer (Tracer mass, Europa Scientific, UK). Algal productiv- ity $(P)$ of each $2 \mathrm{~cm}$ section of the mats was calculated from:

$$
\begin{aligned}
& P\left(\mu \mathrm{mol} C \mathrm{~g} \mathrm{dw}{ }^{-1} \mathrm{~h}^{-1}\right)= \\
& \quad\left({ }^{13} \mathrm{C} \% \text { end }-{ }^{13} \mathrm{C} \% \text { start }\right) \times T C \times\left({ }^{12} \mathrm{DIC} /{ }^{13} \mathrm{DIC}\right) / t
\end{aligned}
$$

where ${ }^{13} \mathrm{C} \%$ start and ${ }^{13} \mathrm{C} \%$ end represent the ${ }^{13} \mathrm{C}$ content of Chaetomorpha linum tissue before and after incubation with $\mathrm{NaH}^{13} \mathrm{CO}_{3}$, respectively. $T C$ is the total $\mathrm{C}$ content, ${ }^{12} \mathrm{DIC} /{ }^{13} \mathrm{DIC}$ the average specific activity of DIC (disolved inorganic carbon) during the incubation, and $t$ the incubation time

The ${ }^{13} \mathrm{C}$ content of DIC in the incubation water was determined in $2 \mathrm{ml}$ water samples collected through silicone stoppered ports in the cylinder wall. The samples were stored in $1.5 \mathrm{ml}$ borosilicate glass vials with PTFE-coated Butyl rubber stoppers, and bacterial activity was stopped by adding $20 \mu 120 \% \mathrm{ZnCl}$ before the samples were transferred to helium filled $5 \mathrm{ml}$ glass vials (Exetainer, Labco, UK). DIC was converted to $\mathrm{CO}_{2}$ by lowering the $\mathrm{pH}$ to 1 by adding $\mathrm{H}_{2} \mathrm{SO}_{4}(4 \mathrm{M}$ ), and shaking vigorously for 10 min to ensure equilibrium of $\mathrm{CO}_{2}$ between the water and gas phases. The headspace was then injected into a gas chromatograph (RoboPrep $\mathrm{G}+$ ) in line with the masspectrometer to determine the isotopic composition of DIC.

Light attenuation within algal mats. Light attenuation within the mats was estimated based on the methods used for weed beds (Westlake 1964) and suspensions of epiphytic microalgae (Sand-Jensen \& Søndergaard 1981). The irradiance in a given position of an algal mat $\left(I_{x}\right)$ can be calculated from:

$$
I_{x}=I_{0} \times \mathrm{e}^{\left(-K_{x} x\right)}
$$

where $I_{0}$ is irradiance penetrating filtered seawater, $K_{x}$ is the vertical extinction coefficient for natural light in a turbid suspension, and $x$ is a quantity factor which may include algal density (a) and distance (d) from the light source. If suspensions of algae behave like suspensions of particles, then:

$$
K_{x} x=k_{a} a+k_{d} d
$$

where $k_{a}$ is the vertical extinction coefficient of the algae and $k_{d}$ is the vertical extinction coefficient due to distance from the light source. $k_{a}$ was derived from measurements of irradiance penetrating through progressively thicker layers of Chaetomorpha linum $\left(I_{a}\right)$ compared to $I_{0}$, using the equation:

$$
k_{a}=\ln \left(I_{0} / I_{a}\right) / a
$$

After each addition of algal material, 3 readings were taken. The algae were redistributed between each reading to ensure a representative distribution of algal filaments. $k_{d}$ was derived in a similar way from measurements of irradiance at increasing distance from the light source when algae were absent. 
Chlorophyll, $\mathrm{C},{ }^{13} \mathrm{C}$ and $\mathrm{N}$ content of the algae. The chlorophyll content was analyzed by a modification of the method described by Wintermanns \& De Motts (1965). Two drops of demineralized water were added to 3 to $5 \mathrm{mg}$ of freeze-dried and ground algal tissue from each depth section of the algal mat. After $2 \mathrm{~h}, 10 \mathrm{ml}$ of $96 \%$ ethanol was added and chlorophyll was extracted in the dark for $16 \mathrm{~h}$ at room temperature. The samples were shaken and centrifuged, and the extinctions at 649 , 665 and $750 \mathrm{~nm}$ were measured on a spectrophotometer.

Total $\mathrm{C},{ }^{13} \mathrm{C}$ and $\mathrm{N}$ content were analyzed on triplicate subsamples of the freeze-dried algal tissue on an elemental analyzer (RoboPrep-C/N) in line with the mass spectrometer.

\section{RESULTS}

\section{Oxygen and nutrient concentrations within the mats}

In the low light experiment, oxygen penetrated approximately $7 \mathrm{~cm}$ down into the algal mat by the end

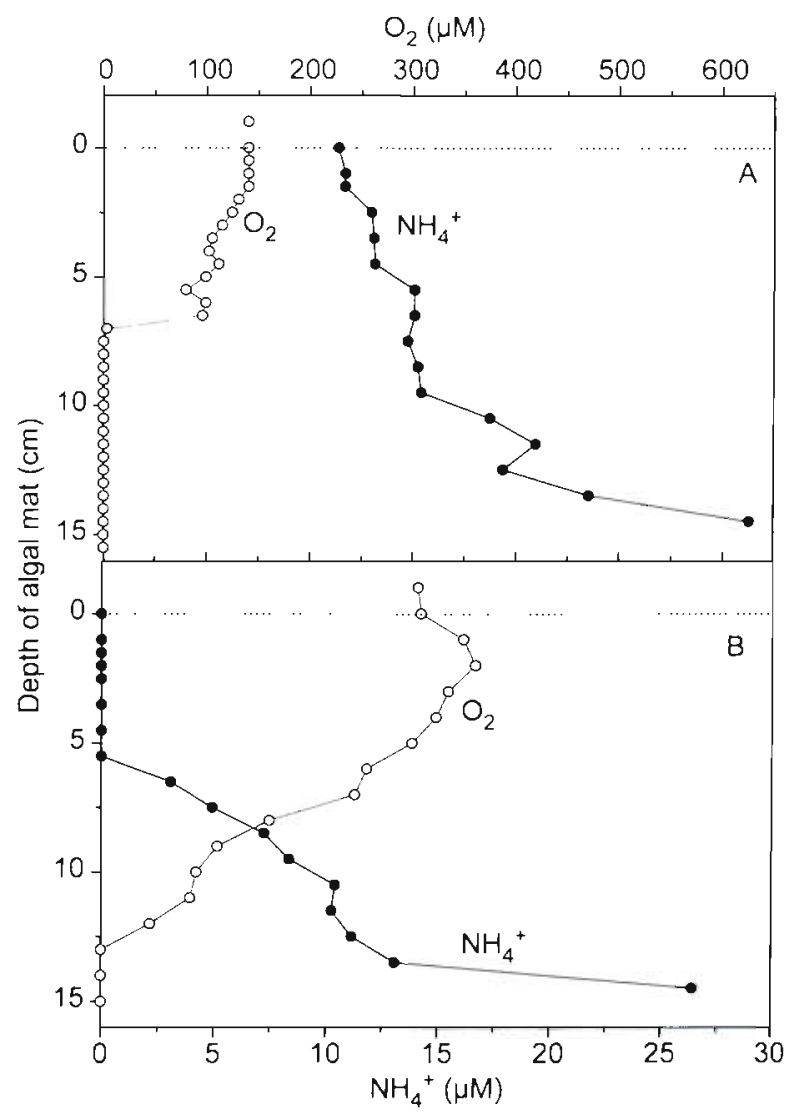

Fig. 2. Chaetomorpha linum. Concentration profiles of $\mathrm{O}_{2}(\mathrm{O})$ and $\mathrm{NH}_{4}{ }^{*}(\bullet)$ measured by depth in a dense mat at (A) the end of dark incubation and $(\mathrm{B})$ the end of light incubation at a low surface irradiance of $120 \mu \mathrm{mol}$ photons $\mathrm{m}^{2} \mathrm{~s}^{-1}$ of the dark period and the mat was anoxic below this depth (Fig. 2A). The $\mathrm{NH}_{4}{ }^{+}$concentration was high in the bottom layers of the mat (up to $30 \mu \mathrm{M}$ ) and decreased up through the mat with distance from the nutrient source. In the dark, a concentration of approximately $10 \mu \mathrm{M} \mathrm{NH}_{4}{ }^{+}$was measured in the upper layer of the mat (Fig 2A). During light exposure, $\mathrm{O}_{2}$ concentrations increased in the upper layers and a maximum concentration of $360 \mu \mathrm{M} \mathrm{O}_{2}$ was measured by the end of the day. The $\mathrm{O}_{2}$ production also increased $\mathrm{O}_{2}$ penetration within the mat to $13 \mathrm{~cm}$ by the end of the light exposure (Fig. 2B). The $\mathrm{NH}_{4}{ }^{+}$concentration in the upper layers was reduced simultaneously with the increase in $\mathrm{O}_{2}$ concentration, and by the end of the day $\mathrm{NH}_{4}{ }^{+}$was not detectable in the upper $6 \mathrm{~cm}$ of the mat although high $\mathrm{NH}_{4}{ }^{+}$concentrations (up to $27 \mu \mathrm{M}$ ) were still found in the bottom of the mat (Fig. 2B).

In the high light experiment, oxygen was present in concentrations corresponding to air saturation in the upper part of the mat at the end of the dark period, and penetrated to $14 \mathrm{~cm}$ depth. Ammonium was only detectable in the bottom $1 \mathrm{~cm}$ layer (Fig. 3A). By the

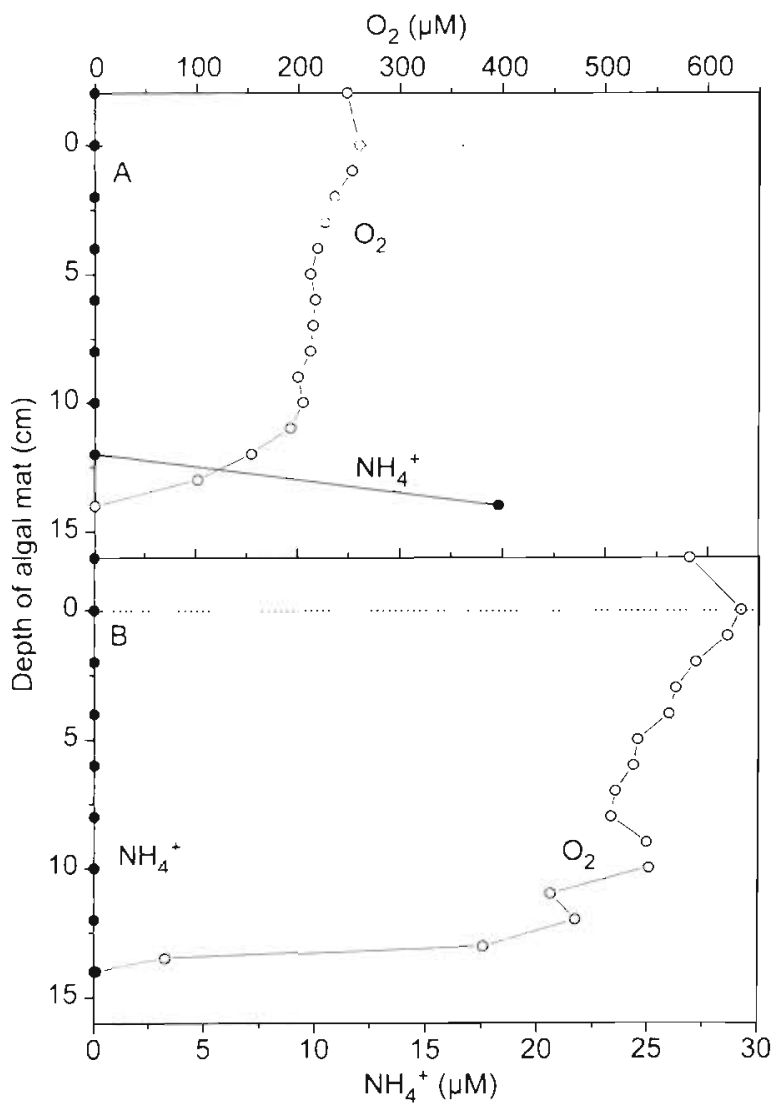

Fig. 3. Chaetomorpha linum. Concentration profiles of $\mathrm{O}_{2}(\mathrm{O})$ and $\mathrm{NH}_{4}{ }^{+}(\bullet)$ measured by depth in a dense mat at (A) the end of dark incubation and (B) end of light incubation at a high surface irradiance of $380 \mu \mathrm{mol}$ photons $\mathrm{m}^{-2} \mathrm{~s}^{-1}$ 
end of the high light incubation, an $\mathrm{O}_{2}$ concentration of $630 \mu \mathrm{M}$ was recorded in the surface layer of the algal mat, and the mat was supersaturated with $\mathrm{O}_{2}$ down to a depth of approximately $13 \mathrm{~cm}$, resulting in large air bubbles surrounding the filaments. Oxygen concentrations were markedly reduced in the lower part of the mat and the bottom $1 \mathrm{~cm}$ of the mat remained anoxic. Ammonium was undetectable within the entire algal mat by the end of the light incubation (Fig. 3B).

\section{Algal production estimated from $\mathrm{O}_{2}$ concentration profiles}

The average net $\mathrm{O}_{2}$ production was $3.65 \mathrm{mmol} \mathrm{O}_{2}$ $\mathrm{m}^{-2} \mathrm{~h}^{-1}$ during the day of the low light experiment (Fig. 4A). The production varied somewhat during the day, showing the lowest values by the end of the day. The average $\mathrm{O}_{2}$ consumption in the dark was $6.69 \mathrm{mmal} \mathrm{O}_{2} \mathrm{~m}^{-2} \mathrm{~h}^{-1}$, giving a diurnal $\mathrm{O}_{2}$ budget of $-36.41 \mathrm{mmol} \mathrm{O}_{2} \mathrm{~m}^{-2} \mathrm{~d}^{-1}$.

During the high light experiment, the average net $\mathrm{O}_{2}$ production decreased from 32.63 to $4.63 \mathrm{mmol} \mathrm{O}_{2} \mathrm{~m}^{-2}$ $\mathrm{h}^{-1}$ during the day, and the average production was $13.17 \mathrm{mmol} \mathrm{O}_{2} \mathrm{~m}^{-2} \mathrm{~h}^{-1}$ (Fig. $4 \mathrm{~B}$ ). The average $\mathrm{O}_{2}$ consumption in the dark was $6.31 \mathrm{mmol} \mathrm{O}_{2} \mathrm{~m}^{-2} \mathrm{~h}^{-1}$, giving a diurnal $\mathrm{O}_{2}$ budget of $82.30 \mathrm{mmol} \mathrm{O}_{2} \mathrm{~m}^{-2} \mathrm{~d}^{-1}$.

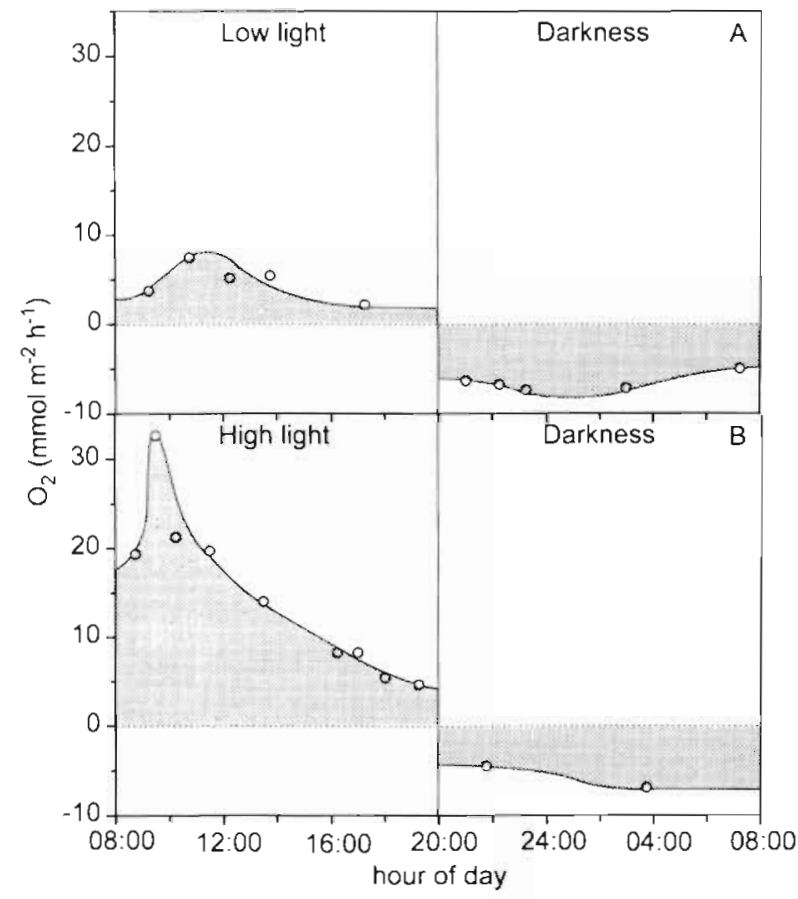

Fig. 4. Chaetomorpha linum. $\mathrm{Net} \mathrm{O}_{2}$ production during a diurnal cycle in dense algal mats incubated at $(A)$ a low surface irradiance of $120 \mu \mathrm{mol}$ photons $\mathrm{m}^{-2} \mathrm{~s}^{-1}$, and (B) a high surface irradiance of $380 \mu \mathrm{mol} \mathrm{m} \mathrm{m}^{-2} \mathrm{~s}^{-1}$

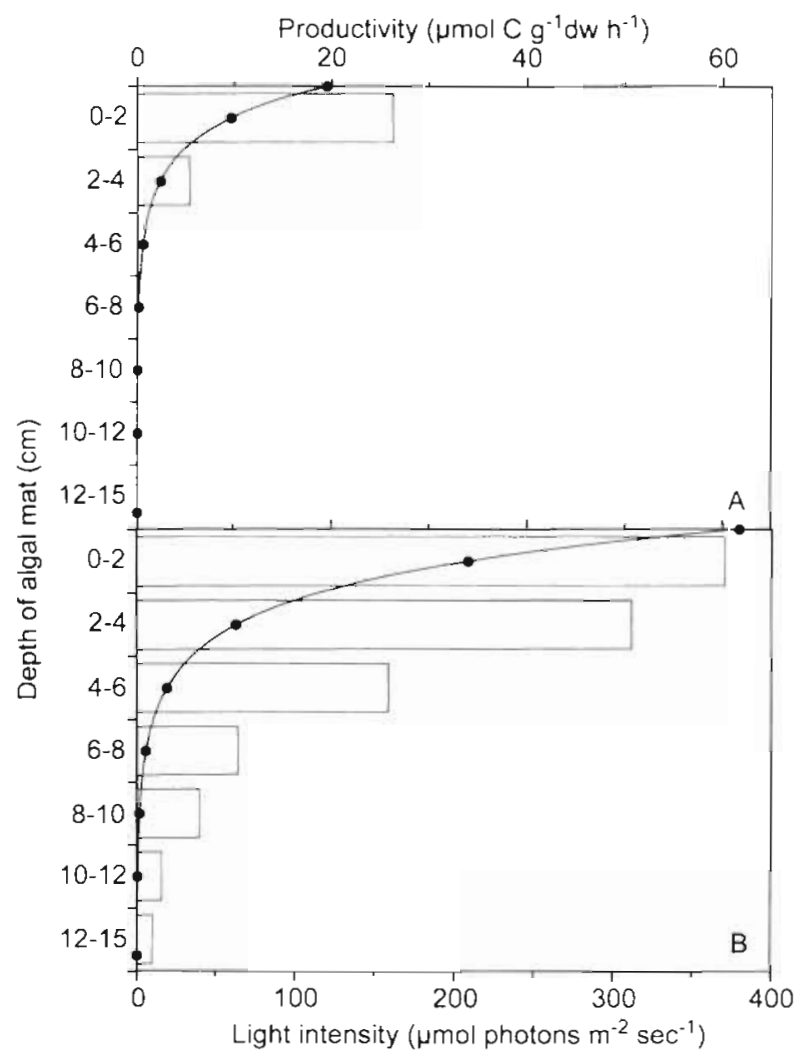

Fig. 5. Chaetomorpha linum. Irradiance (•) and productivity, as measured as ${ }^{13} \mathrm{C}$ incorporation (bars), within algal mats incubated at (A) a low surface irradiance of $120 \mu \mathrm{mol}$ photons $\mathrm{m}^{-2} \mathrm{~s}^{-1}$, and (B) at a high surface irradiance of $380 \mu \mathrm{mol} \mathrm{m}^{-2} \mathrm{~s}^{-1}$

\section{Algal production estimated from ${ }^{13} \mathrm{C}$ uptake}

In both experiments, productivity measured as ${ }^{13} \mathrm{C}$ incorporation was highest in the surface layers and decreased with depth of the mats (Fig. 5). In low light, maximum productivity was $26 \mu \mathrm{mol} \mathrm{C} \mathrm{g}^{-1} \mathrm{dw} \mathrm{h} \mathrm{h}^{-1}$, and production was recorded down to $4 \mathrm{~cm}$ depth (Fig. 5A). In high light, maximum productivity was $60 \mu \mathrm{mol} \mathrm{C} \mathrm{g}^{-1}$ $\mathrm{dw} \mathrm{h}^{-1}$ and the productivity declined to 3 to $4 \%$ of this rate below $10 \mathrm{~cm}$ depth (Fig. 5B). Maximum productivity per unit volume of the water in the mat was 104 in low light and $240 \mu \mathrm{mol} \mathrm{C} \mathrm{l}^{-1} \mathrm{~h}^{-1}$ in high light. The area productivity was 1.9 in low light and $11.1 \mathrm{mmol} \mathrm{C} \mathrm{m}^{-2}$ $\mathrm{h}^{-1}$ in high light.

\section{Light attenuation within algal mats}

The light availability declined exponentially in the algal mats, and the irradiance was reduced to $10 \%$ of surface irradiance at approximately $4.0 \mathrm{~cm}$ depth into the mats (Fig. 5). $k_{a}$ averaged $0.015 \mathrm{~m}^{2} \mathrm{~g}^{-1} \mathrm{dw}(0.0051$ $\mathrm{m}^{2} \mathrm{mg}^{-1} \mathrm{chl}$ ) and $k_{d}$ was $4.46 \mathrm{~m}^{-1}$. The total attenua- 


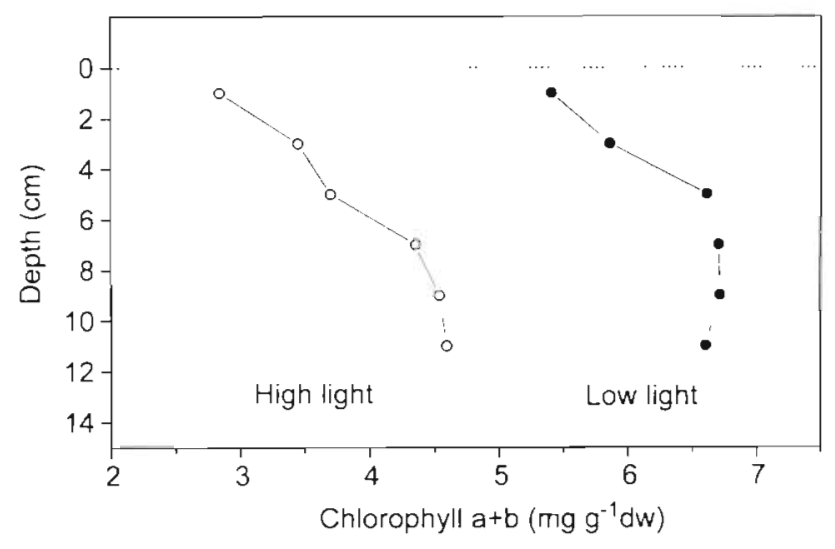

Fig. 6. Chaetomorpha linum. Concentration profiles of chlorophyll content of algal mats incubated at a low surface irradiance of $120 \mu \mathrm{mol}$ photons $\mathrm{m}^{-2} \mathrm{~s}^{-1}(\mathbf{O})$ and at a high surface irradiance of $380 \mu \mathrm{mol} \mathrm{m} \mathrm{m}^{-2} \mathrm{~s}^{-1}$ (O), respectively

tion, $K_{x}\left(\mathrm{~m}^{-1}\right)$, can thus be expressed as

$$
K_{x}=0.015 \times a+4.46
$$

where $a$ is the algal density in $\mathrm{mg} \mathrm{dw} \mathrm{m}^{-3}$.

\section{Chlorophyll, $\mathrm{C}$ and $\mathrm{N}$ content of the algae}

The chlorophyll content was highest in algae from the low light experiment (Fig. 6). In the low light incubated mat, the chlorophyll content increased from 5.4 at the mat surface to $6.6 \mathrm{mg} \mathrm{chl} \mathrm{g} \mathrm{m}^{-1} \mathrm{dw}$ at 5 to $11 \mathrm{~cm}$ depth. In high light, the chlorophyll content increased from $2.8 \mathrm{mg} \mathrm{chl} \mathrm{g}^{-1} \mathrm{dw}$ at the surface to $4.6 \mathrm{mg}$ chl $\mathrm{g}^{-1} \mathrm{dw}$ at 7 to $1.1 \mathrm{~cm}$ depth (Fig. 6).

The $\mathrm{C} / \mathrm{N}$ ratio was lower in algae from the low light experiment compared to algae from the high light experiment (Fig 7). The $\mathrm{C} / \mathrm{N}$ ratio of the algae from the

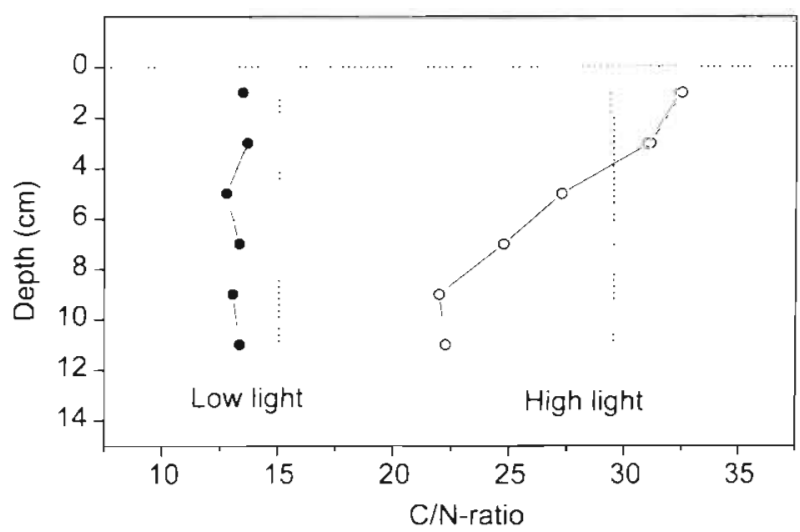

Fig. 7. Chaetomorpha linum. $\mathrm{C} / \mathrm{N}$ ratios of algal mats incubated at a low surface irradiance of $120 \mu \mathrm{mol}$ photons $\mathrm{m}^{-2} \mathrm{~s}^{-1}(\bullet)$, and at a high surface irradiance of $380 \mu \mathrm{mol} \mathrm{m} \mathrm{m}^{-2} \mathrm{~s}^{-1}$ (o). respectively. The dotted lines represent the initial $\mathrm{C} / \mathrm{N}$ ratio of the plant material at the initiation of the experiment low light experiment decreased from 15.1 to $12.8-13.7$ during incubation. There was no significant vertical variation in the $\mathrm{C} / \mathrm{N}$ ratios within the mat. In high light, the initial $\mathrm{C} / \mathrm{N}$ ratio of the algae was 29.6. During incubation, the $\mathrm{C} / \mathrm{N}$ ratio increased to 32.5 in the top of the mat whereas the ratio of the remaining part of the mat gradually decreased to a minimum of 22 in the bottom of the mat, resulting in a distinct vertical $\mathrm{C} / \mathrm{N}$ gradient within the mat (Fig. 7).

\section{DISCUSSION}

\section{Diurnal variations in $\mathrm{O}_{2}$ and nutrient concentrations}

Oxygen profiles were steep within the mats and both $\mathrm{O}_{2}$ concentrations and penetration depth varied markedly between light and darkness, demonstrating dramatic diurnal changes in the $\mathrm{O}_{2}$ environment within the algal mats (Figs. 2 \& 3). Maximum $\mathrm{O}_{2}$ concentrations occurred within the photic zone of the mats at the end of the light period and were more than 2-fold higher than $\mathrm{O}_{2}$ levels in the dark (Figs. $2 \& 3$ ). Similar diurnal changes in $\mathrm{O}_{2}$ concentrations have also been observed within dense mats of Cladophora (Thybo-Christesen et al. 1993, Eiseltová \& Pokorný 1994). Several cm of the algal mats were affected by the changing $\mathrm{O}_{2}$ conditions; in mats of benthic and epiphytic microalgae similar diurnal changes occur, but the $\mathrm{O}_{2}$ dynamics are here restricted to the upper few $\mathrm{mm}$ of the mats (Revsbech et al. 1980, Sand-Jensen et al. 1985).

Oxygen production rates in the macroalgal mats decreased during the day and reached a minimum by the end of the light cycle (Fig. 4). This pattern was most pronounced in high light and may have several reasons. The increase in $\mathrm{O}_{2}$ concentrations during the day (Fig. 3B) is accompanied by DIC depletion and high $\mathrm{pH}$, which may reduce photosynthetic net $\mathrm{O}_{2}$ evolution (Gordon \& Sand-Jensen 1990). High $\mathrm{O}_{2}$ and low $\mathrm{CO}_{2}$ concentrations can reduce photosynthesis due to competition between $\mathrm{O}_{2}$ and $\mathrm{CO}_{2}$ at the reaction sites of RUBISCO. High $\mathrm{O}_{2}$ concentrations can also enhance $\mathrm{O}_{2}$ consumption through dark respiration (Bidwell 1983) and Mehler type reactions associated with the electron transport system (Heber 1985). Photosynthesis may finally decline with increasing time in the light due to an endogenous rhythm in the cells (Harris 1978) or photoinhibitory processes rising in proportion to the light dosis received (Ögren \& Rosenqvist 1992).

High rates of $\mathrm{O}_{2}$ consumption by macroalgal respiration and decomposition processes in the lower part of the algal mats created permanent anoxic conditions at the bottom layers (Figs. 2 \& 3). Permanent anoxia at the sediment surface and markedly reduced light levels may 
prevent development of benthic microalgae, and the low $\mathrm{O}_{2}$ concentrations may also hamper the development of ciliates and meiofauna (Sundbäck et al. 1990). Reducing conditions at the sediment surface simultaneously influence biogeochemical cycles resulting in high effluxes of $\mathrm{PO}_{4}{ }^{3-}, \mathrm{NH}_{4}{ }^{+}$(Lavery \& $\mathrm{McComb} 1991 \mathrm{~b}$ ) and reduced substances such as $\mathrm{H}_{2} \mathrm{~S}$ (Balzer 1984).

Despite the continous high flux of $\mathrm{NH}_{4}{ }^{+}$into the mat from below, macroalgal assimilation significantly reduced ambient $\mathrm{NH}_{4}{ }^{+}$concentrations at the mat surface as a result of photosynthetic activity within the algal mat (Figs. $2 \& 3$ ). In low light the benthic $N$ supply exceeded algal demand and caused a flux of nutrients through the mat in the dark (Fig. 2A). In contrast, the permanently low $\mathrm{NH}_{4}{ }^{+}$concentrations in high light indicated that the nutrient uptake capacity of the algae exceeded the benthic $N$ flux, which was thus efficiently absorbed by the mat (Fig. 3). The algae assimilated 400 and $900 \mu \mathrm{mol} \mathrm{N} \mathrm{m} \mathrm{N}^{-2} \mathrm{~h}^{-1}$ in low light and high light, respectively (McGlathery et al. unpubl.). In addition, coupled nitrification-denitrification activity in the transition zone in the algal mat where the $\mathrm{O}_{2}$ and $\mathrm{NH}_{4}{ }^{+}$ concentration profiles overlap may further reduce $\mathrm{NH}_{4}{ }^{+}$concentrations at a rate of approximately $30 \mu \mathrm{mol}$ $\mathrm{N} \mathrm{m}{ }^{-2} h^{-1}$ (Krause-Jensen et al. unpubl. data). Dense algal mats may thus act as a filter reducing the flux of nutrients to the water column and this effect is most efficient during periods of net growth.

\section{Depth variation in productivity}

Weight-specific productivity decreased in the algal mats as a function of depth, reflecting self-shading by the algae. This pattern is similar to the reduced growth rates at increasing macroalgal density recorded by Lapointe \& Tenore (1981) and Neori et al. (1991). Increased surface irradiance enhanced productivity for a given depth in the algal mat and also extended the productive zone (Fig. 5A, B). The 3 -fold increase in surface irradiance from 120 to $380 \mu \mathrm{mol}$ photons $\mathrm{m}^{-2}$ $\mathrm{s}^{-1}$ thus resulted in more than a doubling of both the maximum weight-specific productivity and also of the productive zone, creating a 6 -fold increase in area productivity of the mat.

The extension of the photic zone (approximately corresponding to the depth of $1 \%$ surface irradiance) is controlled by the vertical light attenuation coefficient and, therefore, by the chlorophyll density of the community (Sand-Jensen 1989). In the algal mat exposed to high surface light, the average chlorophyl\} density was $10.7 \mathrm{~g}$ $\mathrm{chl} \mathrm{m}^{-3}$ and the photic zone was approximately $8 \mathrm{~cm}$ deep. This chlorophyll density is an order of magnitude lower than in dense periphytic mats (e.g. $114 \mathrm{~g} \mathrm{chl} \mathrm{m}^{-3}$; Gilbert 1991), where the photic zone is reduced to a few millimeters at a maximum (Table 1; Revsbech \& Ward 1984). In comparison, stands of submerged plants tend to have less densely packed chlorophyll (approximately 2.1

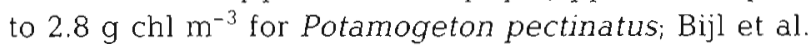
1989, Sand-Jensen pers. comm.), and a deeper photic zone (approximately $14 \mathrm{~cm}$; Bijl et al. 1989), whereas in phytoplankton communities, chlorophyll densities may range from 0.2 to 0.4 in productive lakes (Talling 1973) to $0.00015 \mathrm{~g} \mathrm{chl} \mathrm{a} \mathrm{m}^{-3}$ in oceanic waters (Holm-Hansen et al. 1994), and the photic zone may correspondingly vary between 0.2 and $200 \mathrm{~m}$ (Table 1). Comparison of oceanic phytoplankton communities and microalgal mats shows that the reduction in the extension of the photic zone is accompanied by a $10^{\circ}$-fold increase in maximum volume-specific productivity (Table 1; SandJensen 1989). However, because volume-specific productivity increases as the extension of the photic zone becomes smaller, the total area productivity (i.e. depthintegrated productivity) of the different plant communities is less variable (Table 1 ; Revsbech et al. 1988, SandJensen 1989)

Table 1 Chlorophyll density, photic zone, maximum volume-specific productivity and total productivity of different plant communities

\begin{tabular}{|c|c|c|c|c|c|}
\hline Plant community & $\begin{array}{l}\text { Chlorophyll density } \\
\qquad\left(\mathrm{g} \mathrm{chl} \mathrm{m}^{-3}\right)\end{array}$ & $\begin{array}{l}\text { Photic zone } \\
\text { (m) }\end{array}$ & $\begin{array}{l}\text { Maximum prod } \\
\left(\mu m a l C 1^{-1} h^{-1}\right)\end{array}$ & $\begin{array}{l}\text { Total prod } \\
\left(\mathrm{mmol} \mathrm{C} \mathrm{m}^{-2} \mathrm{~h}^{-1}\right)\end{array}$ & Source \\
\hline Microalgae & $\begin{array}{l}114 \\
-\end{array}$ & $\begin{array}{c}<0.005 \\
0.0005-0.0034\end{array}$ & $\begin{array}{c}- \\
22000-156000^{a}\end{array}$ & $11.8-49.5^{\mathrm{d}}$ & $\begin{array}{l}\text { Gilbert (1991) } \\
\text { Revsbech \& Ward (1984) }\end{array}$ \\
\hline \multicolumn{6}{|l|}{ Macrophytes } \\
\hline Chaetomorpha linum & 16.48 & 0.08 & 240 & 11 & Present study \\
\hline Potamogeton pectinatus & 2.5 & 0.14 & $120^{\mathrm{a}}$ & $15^{.1}$ & $\begin{array}{l}\text { Bijl et al. (1989), } \\
\text { Sand-Jensen (pers. comm.) }\end{array}$ \\
\hline Phytoplankton & $\begin{array}{l}0.21-0.41 \\
0.0035 \\
0.00015\end{array}$ & $\begin{array}{c}0.23-0.49 \\
30 \\
200\end{array}$ & $\begin{array}{l}198-618^{\mathrm{d}} \\
0.2 \\
-\end{array}$ & $\begin{array}{c}12.3-62.5^{\circ} \\
4.8 \\
-\end{array}$ & $\begin{array}{l}\text { Talling et al, (1973) } \\
\text { Nielsen \& Hansen (1995) } \\
\text { Holm-Hansen et al. (1994) }\end{array}$ \\
\hline
\end{tabular}




\section{Depth variation in tissue composition}

The vertical gradients of decreasing irradiance and increasing availability of inorganic nitrogen within the mats were reflected by increasing algal chlorophyll content with depth. The reduced light availability in the low light experiment also resulted in higher chlorophyll content when the 2 light treatments were compared (Fig. 6). An increase in pigment content in response to reduced light levels is a well-known phenomenon which enables the algae to absorb a greater proportion of incident light (Waaland et al. 1974, Markager \& Sand-Jensen 1994). In addition, chlorophyll concentrations typically reflect the macroalgal $\mathrm{N}$ status (Bird et al. 1982, Lapointe \& Duke 1984). The chlorophyll content of Chaetomorpha linum (2.4 to $6.6 \mathrm{mg}$ chl g${ }^{-1} \mathrm{dw}$ ) taken from different depth intervals within the mats of this experiment was thus positively correlated with the tissue $N$ content $\left(y=3.3 x+9.4, R^{2}=\right.$ 0,$89 ; \mathrm{p}<0,001$ in the range of 11.3 to $24.8 \mathrm{mg} \mathrm{N} \mathrm{g}^{-1}$ $\mathrm{dw}$ ). The response in chlorophyll concentrations agrees with the observations of Lapointe \& Tenore (1981) that Ulva fasciata acclimated to decreasing irradiance by increasing the chlorophyll content, and that the algae at each light level increased the chlorophyll content with increasing $\mathrm{N}$ additions. The $\mathrm{C} / \mathrm{N}$ ratio reflects the balance between $\mathrm{C}$ assimilation and $\mathrm{N}$ uptake and provides a relative indicator of possible nutrient limitation within the mat. In low light, low and uniform $\mathrm{C} / \mathrm{N}$ ratios indicated that $\mathrm{C}$ assimilation was low relative to $N$ uptake and that the entire algal mat was probably $N$ saturated and light limited (Fig. 7). The $\mathrm{N}$ sufficiency of the algae was further supported by the relatively high $\mathrm{NH}_{4}{ }^{+}$concentrations in the ambient water at the mat surface (Fig. 2A). In high light, the decrease in $\mathrm{C} / \mathrm{N}$ ratios from surface to bottom of the mat reflected a gradual reduction in $\mathrm{C}$ assimilation relative to $\mathrm{N}$ uptake (Fig. 7 ). This pattern suggested that the bottom layers were light limited and that $N$ limitation became progressively more important towards the mat surface. These $\mathrm{C} / \mathrm{N}$ profiles agree with field measurements of $\mathrm{C} / \mathrm{N}$ ratios decreasing from approximately 25 in the surface to 10 in the bottom layers of $C$. linum mats (Krause-Jensen et al. unpubl. data). The increasing distance between the light source and the sediment nutrient source in actively growing algal mats may thus result in an uncoupling between light and nutrient availability.

\section{Oxygen balance of algal mats}

The $\mathrm{O}_{2}$ balance of the algal mats was markedly affected by light availability. In low light, oxygen consumption exceeded production of the mats giving a negative diurnal $\mathrm{O}_{2}$ budget (Fig. 4A) whereas in high light the mat was net $\mathrm{O}_{2}$ productive over the diurnal cycle (Fig. 4B). A shift from net production to net consumption may similarly occur when algal density increases and the proportion of shaded biomass increases relative to the productive part of the mats. Periods of high temperatures may also stimulate respiration relative to production (Marsh et al. 1986). A negative $\mathrm{O}_{2}$ balance of algal mats may seriously affect shallow macroalgal dominated systems. High respiration rates may lead to anoxia throughout the algal mat and the overlying water column and may cause a significant release of nutrients from both the sediments and decomposing algae (Sfriso et al. 1987, Viaroli et al. 1993, Christensen et al. 1994). Such situations may occur overnight during periods of high temperature and cloudy, moderately calm weather (D'Avanzo \& Kremer 1994). A concomitant release of $\mathrm{H}_{2} \mathrm{~S}$ from the anoxic bottom algal layers and the sediment (Sfriso et al. 1987, Krause-Jensen et al. unpubl. data) dramatically accelerates $\mathrm{O}_{2}$ consumption, and the reducing conditions may finally kill the algae (Drew 1979). This accelerating process may explain the often abrupt declines of dense algal mats (Sfriso et al. 1987, Viaroli et al. 1993, D'Avanzo \& Kremer 1994, Riisgård et al. 1995). Due to the major changes in $\mathrm{O}_{2}$ and nutrient concentrations accompanying the decline of the algae, shallow areas dominated by macroalgal mats can be characterized as unstable systems. Instability may also be caused by an extremely high productivity during periods of calm weather and high irradiance (Fig. 3B), when supersaturation of $\mathrm{O}_{2}$ forms large air bubbles within the mat which may lift part of the mat off the sediment leaving the algae floating at the surface of the water column. Such events may give rise to sudden toxic effects in the water column (e.g. fish kill) due to sediment release of $\mathrm{H}_{2} \mathrm{~S}$, and the enhanced efflux of nutrients may cause a shift from dominance of benthic macroalgae to planktonic microalgae (Christensen et al. 1994).

Acknowledgements. Kaj Sand-Jensen is thanked for constructive criticism and valuable suggestions concerning the manuscript. Tage Dalsgaard, Lars Peter Nielsen and Nils Risgaard are acknowledged for help during the analysis of $\mathrm{O}_{2}$ concentration profiles. Kitte Gerlich, Marlene V. Jessen and Preben G. Sorensen are thanked for skilful technical assistance. We are grateful to Niels Peter Revsbech for supplying $\mathrm{O}_{2}$ microsensors. The work was financially supported by the Danish Agency of Environmental Protection through the Marine Research 1990 Programme.

\section{LITERATURE CITED}

Artebjerg G, Sandbeck P. Agger CT, Rasmussen B, Kaas H, Jensen NJ, Krause-Jensen D, Christensen PB (1993) Marine omrăder-fjorde, kyster og abent hav. The moni- 
toring programme under the action plan for the aquatic environment 1992. Ministry of the environment, National Environmental Research Instıtute, Denmark, Technical report no. 89 (in Danish with English summary)

Balzer W (1984) Organic matter degradation and biogenic element cycling in a nearshore sediment (Kiel Bight). Limnol Oceanogr 29(6):1231-124

Bidwell RGS (1983) Carbon nutrition of plants: photosynthesis and photorespiration. In: Steward FC, Bidwell RGS (eds) Plant physiology. A treatise, Vol VII. Energy and carbon metabolism. Academic Press, New York, p 287-457

Bijl L van der, Sand-Jensen K, Hjermind AL (1989) Photosynthesis and canopy structure of a submerged plant, Potamogeton pectinatus, in a Danish lowland stream. J Ecol $77: 947-962$

Bird KT, Habig C, DeBusk T (1982) Nitrogen allocation and storage patterns in Gracilaria tikvahiae (Rhodophyta). J Phycol 18:344-348

Bower E, Hansen HA (1980) A salicylate-hypochlorite method for determining ammonia in seawater. Can J Fish Aquat Sci 37:794-798

Christensen PB (ed) (1994) Stoftransport og stofomsœtning Kertınge Nor/Kerteminde Fjord. Havforskning fra miljostyrelsen nr 43, Ministry of the Environment, Denmark (in Danish with English summary)

Coutinho R, Zingmark R (1993) Interactions of light and nitrogen on photosynthesis and growth of the marine macroalga Ulva curvata (Kützing) De Toni. J Exp Mar Biol Ecol 167:11-19

D'Avanzo C, Kremer JN (1994) Diel oxygen dynamics and anoxic events in a eutrophic estuary of Waquoit Bay. Estuaries 17 (18): 131-139

Drew MC (1979) Plant responses to anaerobic conditions in soil and solution culture. Curr Adv Plant Sci 36:1-32

Eiseltová M, Pokorný J (1994) Filamentous algae in fish ponds of the Třebon Biosphere Reserve-ecophysiological study. Vegetatio 113:155-170

Gilbert NS (1991) Microphytobenthic seasonality in nearshore marine sediments at Signy Island, South Orkney Islands, Antartica. Estuar Coast Shelf Sci 33:89-104

Gordon DM, McComb AJ (1989) Growth and production of the green alga Cladophora montagneana in a eutrophic Australian estuary and its interpretation using a computer program. Wat Res 23 (5): $633-645$

Gordon DM, Sand-Jensen $\mathrm{K}$ (1990) Effects of $\mathrm{O}_{2}, \mathrm{pH}$ and DlC on photosynthetic net- $\mathrm{O}_{2}$ evolution by marine macroalgae. Mar Biol 106:445-451.

Grasshoff K. Erhardt M, Kremling K (1983) Methods of seawater analysis, 2nd rev and extended edn. Verlag Chemie, Weinheim

Harris GP (1978) Photosynthesis and growth: the physiological ecology of phytoplankton. Arch Hydrobiol Beih Ergeb Limnol 10 (I-IV):1-171

Heber $U$ (1985) Interaction of oxygen with the electron transport chain of photosynthesis. In: Viil A, Grishina GS, Laisle AK (eds) Kinetics of photosynthetic carbon metabolism in C3 plants II. Electron transport. Transport of $\mathrm{CO}_{2}$. Mathematical models. Scientific council on photosynthesis and plant photobiology. Academy of Sciences of the USSR, Estonian Academy of Sciences, Tallinn 'Valgus', p 9-22

Holm-Hansen O, Amos AF, Nelson SS, Villafane V, Hebling EW (1994) In situ evidence for a nutrient limitation of phytoplankton in pelagic Antartic waters. Antart Sci 6(3): 315-324

Lapointe BE, Duke CS (1984) Biochemical strategies for growth of Gracilaria tikvahiae (Rhodophyta) in relation to light intensity and nitrogen availability. $J$ Phycol 20: $488-495$

Lapointe BE, Tenore KR (1981) Experimental outdoor studies with UIva fasciata Delile. 1. Interaction of light and nitrogen on nutrient uptake, growth and biochemical composition. J Exp Mar Biol Ecol 53:135-152

Lavery PS, McComb AJ (1991a) The nutritional eco-physiology of Chaetomorpha linum and Ulva rigida in Peel Inlet, Western Australia. Bot Mar 34:251-260

Lavery PS, McComb AJ (1991b). Macroalgal-sediment nutrient interactions and their importance to macroalgal nutrition in a eutrophic estuary. Estuar Coast Shelf Sci 32: $281-295$

Lavery PS, Lukatelich RJ, McComb AJ (1991) Changes in the biomass and species composition of macroalgae in a eutrophic estuary. Estuar Coast Shelf Sci 33:1-22

Markager S, Sand-Jensen K (1994) The physiological ecology of light-growth relationship in macroalgae. Prog Phycol Res 10:209-298

Marsh JA Jr, Dennison WC. A.lberte RS (1986) Effects of temperature on photosynthesis and respiration in eelgrass (Zostera marina L.). J Exp Mar Biol Ecol 101:257-267

Neori A, Cohen I. Gordin H (1991) Ulva lactuca biofilters for marine fishpond effluents. II. Growth rate, yield and $\mathrm{C}: \mathrm{N}$ ratio. Bot Mar 34:483-489

Nielsen TG, Hansen B (1995) Plankton community structure and carbon cycling in Arctic West Greenland during and after the sedimentation of a diatom bloom. Mar Ecol Prog Ser 125:239-257

Ögren E, Rosenqvist E (1992) On the significance of photoinhibition of photosynthesis in the field and its generality among species. Photosynth Res 33:63-71

Olesen B (1989) Vokstregulering hos makroalger i et lavvandet kystområde, MSc thesis, Botanical Department, University of Århus

Pedersen MF (1993) Growth and nutrient dynamics in marine plants. PhD thesis, Freshwater-Biological Laboratory, University of Copenhagen

Revsbech NP (1989) An oxygen microelectrode with a guard cathode. Limnol Oceanogr 34:474-478

Revsbech NP, Nielsen J, Hansen PK (1988) Benthic primary production and oxygen profiles. In: Blackburn TH, Sorensen $J$ (eds) Nitrogen cycling in coastal marine environments. John Wiley, New York, p 69-83

Revsbech NP, Sørensen J, Blackburn TH, Lomholt JP (1980) Distribution of oxygen in marine sediments measured with microelectrodes. Limnol Oceanogr 25:403-411

Revsbech NP, Ward DM (1984) Microelectrode studies of interstitial water chemistry and photosynthetuc activity in a hot spring microbial mat. Appl Environ Microbiol 48: $270-275$

Riisgård HU, Christensen PB, Olesen NJ, Petersen JK, Moller MM, Andersen P (1995) Biological structure in a shallow cove (Kertinge Nor, Denmark) - control by benthic nutrient fluxes and suspension feeding ascidians and jellyfish. Ophelia 41:329-344

Sand-Jensen K (1989) Environmental variables and their effect on photosynthesis of aquatic plant communities. Aquat Bot 34:5-25

Sand-Jensen K, Madsen TV (1991) Minimum light requirements of submerged freshwater macrophytes in laboratory growth experiments. J Ecol 79:749-764

Sand-Jensen K, Revsbech NP, Jørgensen, BB (1985) Microprofiles of oxygen in epiphytic communities on submerged macrophytes. Mar Biol 89:55-62

Sand-Jensen K, Sondergaard M (1981) Phytoplankton and epiphyte development and their shading effect on sub- 
merged macrophytes in lakes of different nutrient status. Int Revue Ges Hydrobiol 66:529-552

Sfriso A, Marcomini A, Pavoni B (1987) Relationships between macroalgal biomass and nutrient concentrations in a hypertrophic area of Venice Lagoon. Mar Environ Res 22:297-312

Sfriso A, Marcomini A, Pavoni B, Orio AA (1993) Species composition, biomass, and net primary production in shallow coastal waters: the Venice Lagoon. Biores Technol 44: $235-250$

Sundbäck K, Jönsson B, Nilsson P, Lindström I (1990) Impact of accumulating drifting macroalgae on a shallow-water sediment system: an experimental study. Mar Ecol Prog Ser 58:261-274

Talling JF, Wood RB, Prosser MV, Baxter RM (1973) The upper limit of photosynthetic productivity by phytoplankton: evidence from Ethiopian soda lakes. Freshwat Biol 3:53-76

Thybo-Christesen M, Blackburn $\mathrm{H}$ (1993) Internal $N$ cycling, measured by ${ }^{15} \mathrm{NH}_{4}{ }^{+}$dilution, in Cladophora sericea in a shallow Danish bay. Mar Ecol Prog Ser 100:283-286

Thybo-Christesen M, Rasmussen MB, Blackburn TH (1993) Nutrient fluxes and growth of Cladophora sericea in a shallow Danish bay. Mar Ecol Prog Ser 100:273-281

This article was submitted to the editor
Valiela I. Foreman K, LaMontagne $M$, Hersh D, Costa $J$, Peckol P, DeMeo-Anderson B, D'Avanco C, Babione M, Sham CH. Bawley J, Lajhta K (1992) Couplings of watersheds and coastal waters: sources and consequences of nutrient enrichment in Waquoit Bay, Massachusetts. Estuaries 15:443-457

Viaroli P, Bartoli M, Bondavalli C, Naldi M, Ferrari 1 (1993) Macroalgae growth and decomposition and nutrient cycling in the Sacca di Goro (Po River Delta). In: Caumette $P$ (ed) Commission of the European Communities Enviromental Research Programme C.L.E.AN (Coastal Lagoon Eutrophication and Anaerobic Processes) Progress report. 1993, part II. Proceedings of the CLEAN meeting Alicante 3-5 Dec 1993. Bordeaux University, France, p 281-307

Waaland JR, Waaland SD, Bates G (1974) Chloroplast structure and pigment composition in the red alga Griffithsia pacifica: regulation by light intensity. J Phycol 10:193-199

Westlake DF (1964) Light extinction, standing crop and photosynthesis within weed beds. Verh Int Verein Limnol 15: $415-425$

Wintermanns JFGM, De Motts A (1965) Spectrophotometric characteristics of chlorophyll $a$ and $b$ and their pheophytins in ethanol. Biochem Biophys Acta 109:448-453

Manuscript first received: September 4, 1995

Revised version accepted: November 14, 1995 